\author{
Research Article
}

\title{
ROLE OF BALA TAILA NASYA AND RASNADI GUGGULU IN KARNASRAVA (CHRONIC SUPPURATIVE OTITIS MEDIA)
}

\section{Deepti Negi ${ }^{*}$, Radhakrishna Bishwal ${ }^{2}$, Aditi $^{3}$ \\ ${ }^{*}$ PG Scholar, 2 Professor, ${ }^{3}$ Assistant Professor, Dept. of Shalakya Tantra, Uttarakhand Ayurveda University, Gurukul Campus, Haridwar, Uttarakhand, India.}

\begin{tabular}{|c|c|}
\hline Article info & ABSTRACT \\
\hline Article History: & hi in \\
\hline 2-12-2021 & heans Srava \\
\hline 021 & m OPD/IPD of \\
\hline Accepted: 10-01-2022 & hasrava/CSOM. \\
\hline $\begin{array}{l}\text { KEYWORDS: } \\
\text { Karnasrava, CSOM, } \\
\text { Bala Taila Nasya, } \\
\text { Rasnadi Guggulu } \\
\text { etc. }\end{array}$ & $\begin{array}{l}\text { There was only one group, so combined effect of Bala Taila Nasya and Rasnadi Guggulu } \\
\text { was seen in patients. Results of the study indicates that highly significant result was seen } \\
\text { in earache, Karnasrava (quantity of discharge), tenderness over mastoid antrum and } \\
\text { consistency of discharge. Not significant result was seen in degree of hearing loss while in } \\
\text { T.M. perforation size result was only significant. }\end{array}$ \\
\hline
\end{tabular}

\section{INTRODUCTION}

Karnasrava is a disease mentioned by Acharya Sushruta in the chapter named Karnaroga Vigyaniya under twenty eight Karnaroga ${ }^{[1]}$. In Ayurveda Karnasrava is described as separate disease as well as symptom of so many Karnaroga like Putikarna and Karnapaka[2]. Acharya Charaka mentioned Karnasrava as symptom of four types of Karnaroga[3]. According to Ashtanga Hridaya and Ashtanga Sangraha Karnasrava is one of the important symptom among all the five Karnashoola Roga[4,5]. Karnasrava is the condition described as discharge from Karna and which occurs due to vitiation of all the three Dosha, symptoms of Karnasrava resembles with the Chronic Suppurative Otitis Media (CSOM). Chronic Suppurative Otitis Media is a long-standing infection of the middle ear cleft, characterized by a permanent perforation of tympanic membrane and ear discharge. CSOM is of two types: Tubotympanic type (safe or benign) of CSOM and Atticoantral type (dangerous or unsafe) of CSOM[6].

In year 1997, a worldwide survey on prevalence of CSOM was done by WHO.

\begin{tabular}{|l|l|}
\hline \multicolumn{3}{|c|}{ Access this article online } \\
\hline Quick Response Code & \\
\hline Published by Mahadev Publications (Regd.) \\
publication licensed under a Creative \\
Commons Attribution-NonCommercial- \\
ShareAlike 4.0 International (CC BY-NC-SA 4.0)
\end{tabular}

It states that $7.8 \%$ of school children of India were affected of CSOM which came under highest (>4\%) group who needed urgent attention to deal with a massive public health problem ${ }^{[7]}$.

This disease is commonly observed in developing countries, may be because of low socioeconomic standards or lack of health awareness. In modern science main treatment of Chronic Suppurative Otitis Media include topical antibiotics with or without steroids, systemic antibiotics, topical antiseptics and wet or dry aural toileting. According to Acharya Sushruta general treatment of Karnasrava includes Shirovirechana, Dhupana, Karnapurana, Pramarjana, Dhavana, Prakshalana etc ${ }^{[8]}$.

Acharya Sushruta has mentioned Bala Taila in Chikitsa Sthan under Mudhgarbha Chikitsa Adhyaya[9], later on he had mentioned the same Taila in Uttar Tantra under Karnaroga Pratishedha Adhyaya[10]. Rasnadi Guggulu is the drug mentioned in Karna Roga Adhikara in Yogratnakara. It is said to be used in Vata Roga, Karna Roga, Shiroroga, Nadivrana and Bhagandar[11].

For this trial 30 patients were registered and treated with Bala Taila Nasya and Rasnadi Guggulu. The duration of treatment was 17 days. Bala Taila Nasya was given in two sittings of seven days each with an interval of three days. Madhyama Matra of Shirovirechan Nasya i.e., 6 Bindu (approx 3ml) was indicated for the management of Karnasrava. 
Rasnadi Guggulu was given for oral administration for 17 days. Its dose was decided i.e., for patients aged 10-16 yrs- $250 \mathrm{mg}$ BD, and for patients aged $>16$ yrs- $500 \mathrm{mg}$ BD.

\section{MATERIAL AND METHODS}

\section{AIMS AND OBJECTIVES}

1. Review of conceptual study of Karna Sharira.

2. To study the disease Karnasrava in Ayurvedic and modern classics.

3. To assess the role of Bala Taila Nasya and Rasnadi Guggulu in Karnasrava.

\section{Criteria for Selection of Patients}

\section{Inclusion Criteria}

1. Patient between the age group of 10 to 60 years were included for the study.

2. Patient had the symptoms of Vedna (earache), Karnasrava (ear discharge), perforation of TM, hearing impairment and tenderness over mastoid antrum.

3. Clinically confirming the symptoms of Karnasrava (Chronic Suppurative Otitis Media) by Otoscopic examination.

4. Tubotympanic type of Chronic Suppurative Otitis Media.

\section{Exclusion Criteria}

1. Patient with complications of chronic suppurative otitis media.

2. Patient suffering from Diabetes Mellitus, HTN and Tuberculosis.

3. Pregnant and lactating females.

4. Patient below the age of 10 and above 60 years.

5. Atticoantral type of Chronic Suppurative Otitis Media.

6. Sensorineural hearing loss.

\section{Nature of Clinical Study}

This clinical study was carried out in three phases:

a) Diagnostic phase

b) Interventional phase

c) Assessment phase

\section{Criteria for Diagnosis}

Following subjective and objective parameters were considered for diagnosis of Karnasrava (Chronic Suppurative Otitis Media)

\section{Subjective Parameters}

\section{Earache}

\begin{tabular}{|l|l|}
\hline Absent & 0 \\
\hline Mild pain (do not affect sleep and routine work) & 1 \\
\hline $\begin{array}{l}\text { Moderate pain (affecting sleep but not routine } \\
\text { work) }\end{array}$ & 2 \\
\hline Severe pain (affecting sleep and routine work) & 3 \\
\hline
\end{tabular}

Karnasrava (Quantity of Discharge)

\begin{tabular}{|l|l|}
\hline Absent & 0 \\
\hline Secretion near Tympanic membrane & 1 \\
\hline Secretion irrigating in the ear canal & 2 \\
\hline Secretions coming out of ear canal & 3 \\
\hline
\end{tabular}

Degree of Hearing Loss

\begin{tabular}{|l|c|}
\hline Able to hear whispers & 0 \\
\hline $\begin{array}{l}\text { Able to hear and repeat word spoken } \\
\text { in normal voice }(1 \mathrm{~m})\end{array}$ & 1 \\
\hline $\begin{array}{l}\text { Able to hear repeat words spoken in } \\
\text { raised voice }(1 \mathrm{~m})\end{array}$ & 2 \\
\hline $\begin{array}{l}\text { Able to hear words when shouted } \\
\text { into better ear }\end{array}$ & 3 \\
\hline
\end{tabular}

\section{Consistency of Discharge}

\begin{tabular}{|l|l|}
\hline Serous & 0 \\
\hline Mucoid & 1 \\
\hline Mucopurulent & 2 \\
\hline Purulent & 3 \\
\hline
\end{tabular}

\section{Tenderness over Mastoid Antrum}

\begin{tabular}{|l|l|}
\hline Tolerance to pressure & 0 \\
\hline Little response on sudden pressure & 1 \\
\hline Wincing on face on super slight touch & 2 \\
\hline Resists to touch & 3 \\
\hline
\end{tabular}

\section{Objective Parameter}

T.M. Perforation Size

\begin{tabular}{|l|l|}
\hline $\begin{array}{l}\text { Pin point perforation (<25\% and involving } \\
\text { one quadrant) }\end{array}$ & 0 \\
\hline $\begin{array}{l}\text { Perforation size (25- } 50 \% \text { and involving } \\
\text { two quadrants) }\end{array}$ & 1 \\
\hline $\begin{array}{l}\text { Large perforation (50-75\% and involving } \\
\text { three quadrants) }\end{array}$ & 2 \\
\hline $\begin{array}{l}\text { Complete or Total perforation }(>75 \% \& \\
\text { involving four quadrants) }\end{array}$ & 3 \\
\hline
\end{tabular}

\section{Functional Examination of Ear}

1. External examination: A complete examination of ear was done with the help of torch light to rule out any abnormality.

2. Palpation: Tenderness over mastoid antrum was elicited by pressing with tip of forefinger or thumb on area of mastoid.

3. Otoscopic examination: This examination was done to rule out T.M. perforation size.

4. Tunning Fork test: This examination was done to differentiate between conductive deafness and sensorineural hearing loss. After this examination, patients with sensorineural hearing loss were excluded from this study. 
In present study, WHO's criteria for assessment of hearing loss was taken which was favourable for younger as well as elder patients, where only repetition of words were required.

\section{Investigations}

- $\mathrm{Hb} \%$

- TLC

- DLC

- ESR

- RBS

\section{Interventional Phase}

Drugs and Posology

\section{Bala Taila Nasya}

Before Bala Taila Nasya, regular cleaning of patient's affected ear was done with sterile cotton tipped jobson horne probe.

Dose of Nasya- Madhyama Matra of Shirovirechan Nasya - 6 Bindu ( $3 \mathrm{ml}$ approx)

Duration- For seven days in two sittings with an interval of three days (total seventeen days).

Form - Oil

Route and form of administration - Nose.

\section{Rasnadi Guggulu}

Dose - 250mg BD for patient less than age of 16yr. $500 \mathrm{mg}$ Bd for patients age above 16 years.

Duration- For seventeen days.

Form- Tablet

Route and form of administration - Oral

\section{Assessment phase}

\section{Criteria for the Assessment}

The overall effect of Rasnadi Guggulu and Bala Taila Nasya was assessed as-

\begin{tabular}{|l|l|}
\hline Cured & $\begin{array}{l}80-100 \% \text { relief in } \\
\text { symptoms }\end{array}$ \\
\hline Marked improvement & $\begin{array}{l}60-79 \% \text { relief in } \\
\text { symptoms }\end{array}$ \\
\hline $\begin{array}{l}\text { Moderate } \\
\text { improvement }\end{array}$ & $\begin{array}{l}40-59 \% \text { relief in } \\
\text { symptoms }\end{array}$ \\
\hline Mild improvement & $\begin{array}{l}20-39 \% \text { relief in } \\
\text { symptoms }\end{array}$ \\
\hline No improvement & $\begin{array}{l}\text { less than or equal to 19\% } \\
\text { relief in symptoms }\end{array}$ \\
\hline
\end{tabular}

\section{Statistical Analysis}

All information on subjective and objective parameters was gathered and statistical study was carried out in terms of Mean, Standard deviation (S.D.), Standard error (S.E.) Wilcoxon's signed rank- Test and paired t test before and after treatment in all the patients. Results were incorporated in terms of probability (p) as:

- $\mathrm{p}>0.05$ - Insignificant

- $\mathrm{p}=0.01-0.05-$ Significant

- $\mathrm{p}=0.001-0.01$ - very significant

- $\mathrm{p}<0.001$ - Highly significant

\section{OBSERVATIONS AND RESULTS}

In this clinical trial of Karnasrava (CSOM) total 30 patients were registered and kept in a single group. As per observation out of 30 patients maximum $36.67 \%$ patients were from age group 21-30 years. Most of the patients registered in this study who affected more were females (67\%). Maximum registered patients were from lower middle class family i.e., $40 \%$. rural patients (87\%) were more affected in comparison to urban patients. Majority of patients $43 \%$ had chronicity of more than 1 year, 1 patient $(3 \%)$ had chronicity of 10-12 months, 2 patients $(7 \%)$ had chronicity of 7-9 months, 5 patients (17\%) had chronicity of 4-6 months and 9 patients (30\%) had chronicity of 1-3 months. Out of 30 patients 16 patients $(60 \%)$ had deviated nasal septum. Among 30 patients 6 patients (20\%) were of VP Prakriti, 8 patients $(27 \%)$ were of $P K$ Prakriti and maximum 16 patients (53\%) were of VK Prakriti.

Among 30 patients earache, discharge, consistency of discharge and TM perforation were seen in all 30 patients $(100 \%)$, degree of hearing loss was seen in 24 patients (80\%) and Tenderness over mastoid antrum was found in only 13 patients (43.33\%).

\section{RESULTS}

In total registered patients by applying Wilcoxon Signed Rank test on subjective parameters it was found that symptom of earache improved by $90.90 \%$ and was statistically highly significant ( $\mathrm{p}$ value $<0.0001$ ). Symptom of discharge improved by $75 \%$ which was statistically highly significant ( $p$ value $<0.0001$ ). Degree of hearing loss improved by only $9.75 \%$ which was statistically not significant ( $\mathrm{p}$ value 0.0625). Symptom of consistency of discharge improved by $85.96 \%$ which was statistically highly significant ( $p$ value $<0.0001$ ). Symptom of tenderness over mastoid antrum improved by $66.66 \%$ which was statistically highly significant ( $p$ value $<0.0002$ ).

By applying Paired $t$ test on objective parameter it was found that sign of TM perforation size improved by only $7.27 \%$ which was statistically significant ( $\mathrm{p}$ value 0.0217 ). 
Deepti Negi et al. Role of Bala Taila Nasya and Rasnadi Guggulu in Karnasrava (Chronic Suppurative Otitis Media)

Result of Effect of Therapy of 30 Patients on Subjective Parameters (Wilcoxon Signed Rank test)

\begin{tabular}{|l|l|c|c|c|c|c|c|c|c|c|}
\hline S.no. & Parameters & & \multicolumn{3}{|c|}{ Means } & S. D. & S.E. & \% Effect & P value & Result \\
\hline 1 & Earache & 30 & 2.2 & 0.2 & 2 & 0.6948 & 0.1269 & $90.90 \%$ & $<0.0001$ & $\begin{array}{c}\text { Highly } \\
\text { significant }\end{array}$ \\
\hline 2 & Discharge & 30 & 2 & 0.5 & 1.5 & 0.5724 & 0.1045 & $75 \%$ & $<0.0001$ & $\begin{array}{c}\text { Highly } \\
\text { significant }\end{array}$ \\
\hline 3 & $\begin{array}{l}\text { Degree of Hearing } \\
\text { Loss }\end{array}$ & 24 & 1.70 & 1.54 & 0.16 & 0.3457 & 0.06312 & $9.75 \%$ & 0.0625 & $\begin{array}{c}\text { Not } \\
\text { significant }\end{array}$ \\
\hline 4 & $\begin{array}{l}\text { Consistency of } \\
\text { Discharge }\end{array}$ & 30 & 1.90 & 0.27 & 1.63 & 0.4901 & 0.08949 & $85.96 \%$ & $<0.0001$ & $\begin{array}{c}\text { Highly } \\
\text { significant }\end{array}$ \\
\hline 5 & $\begin{array}{l}\text { Tenderness Over } \\
\text { Mastoid Antrum }\end{array}$ & 13 & 1.84 & 0.61 & 1.23 & 0.7303 & 0.1333 & $66.66 \%$ & 0.0002 & $\begin{array}{c}\text { Highly } \\
\text { significant }\end{array}$ \\
\hline
\end{tabular}

Result of Effect of Therapy of 30 Patients on Objective Parameters (Paired t test)

\begin{tabular}{|l|l|c|c|c|c|c|c|c|c|c|}
\hline S.no. & Parameters & & \multicolumn{3}{|c|}{ means } & S. D. & S.E. & \% Effect & P value & Result \\
\hline & & N & BT & AT & D & & & & & \\
\hline 1 & T M Perforation & $\mathbf{3 0}$ & 1.83 & 1.7 & 0.13 & 0.3457 & 0.06312 & $7.27 \%$ & 0.0217 & Significant \\
\hline
\end{tabular}

\section{$\%$ Relief in Patients}

In total registered patients symptom of earache improved by $90.90 \%$, symptom of discharge improved by $75 \%$, degree of hearing loss improved by only $9.75 \%$, symptom of consistency of discharge improved by $85.96 \%$, symptom of tenderness over mastoid antrum improved by $66.66 \%$ and sign of TM perforation size improved by only $7.27 \%$.

\section{\% RELIEF}

EARACHE

- DEGREE OF HEARING LOSS

T.M. PERFORATION SIZE
DISCHARGE

- CONSISTENSY OF DISCHARGE

- TENDERNESS OVER MASTOID ANTRUM

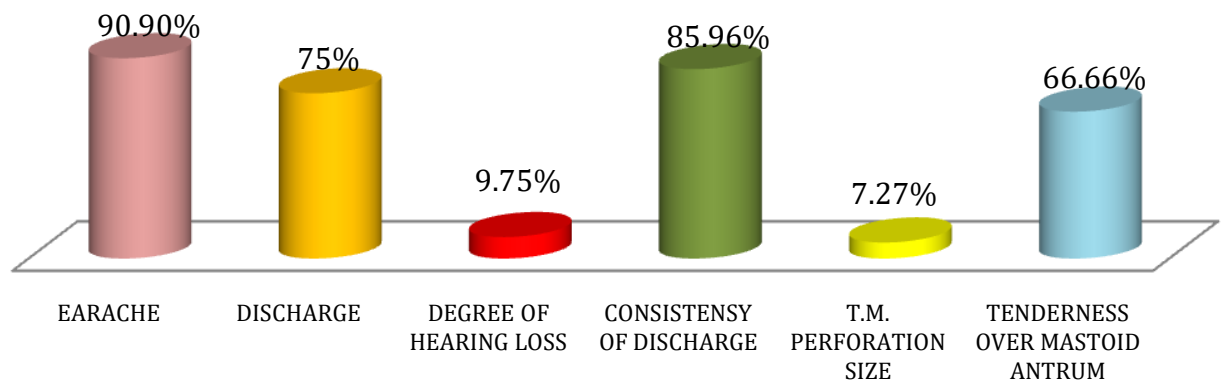




\section{Overall Assessment of Result}

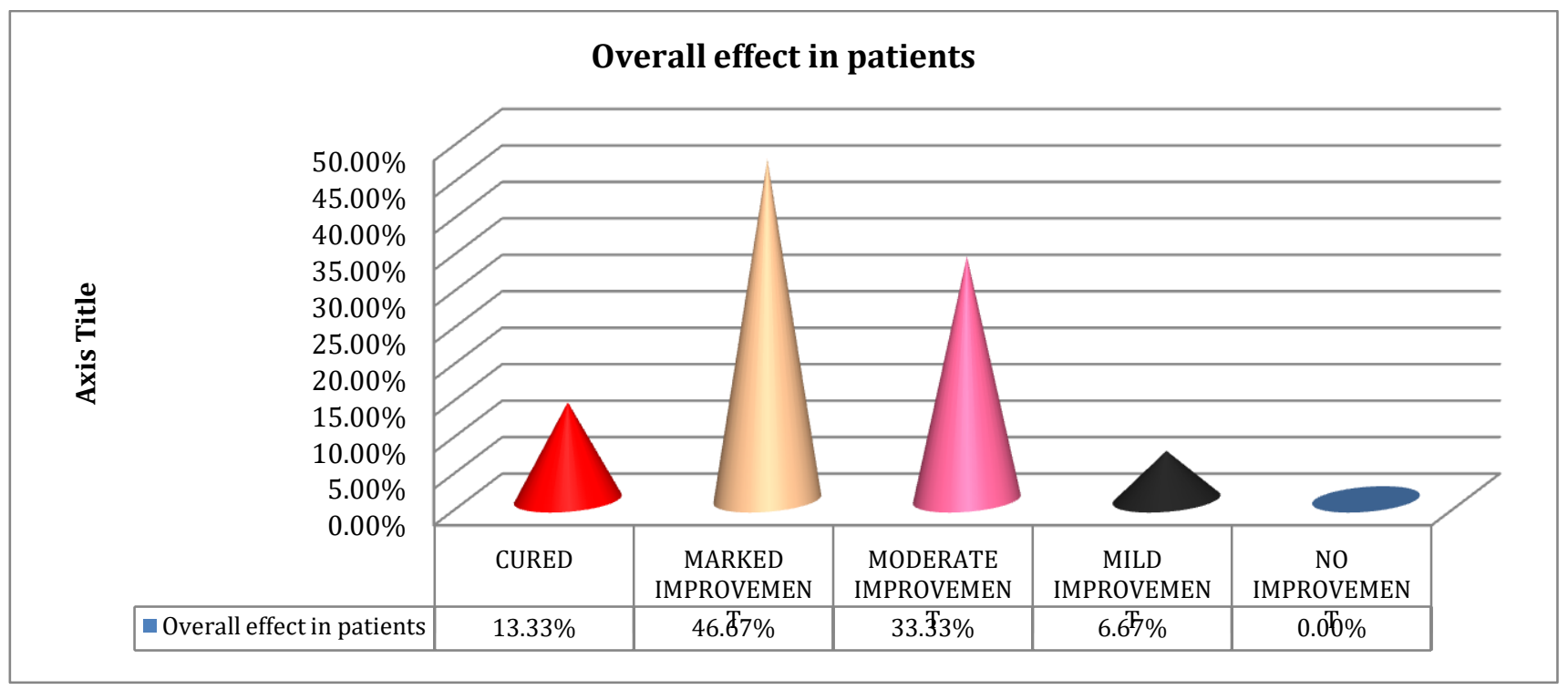

- 04 patients $(13.33 \%)$ were cured.

- Marked improvement was seen in 14 patients (46.67\%)

- Moderate improvement was seen in 10 patients (33.33\%)

- Mild improvement was seen in 02 patients (6.67\%)

- No improvement was seen in $00.00 \%$ patient.

\section{DISCUSSION}

Patients belonged to rural area i.e., 26 patients (87\%) were more affected. This was due to most area near the hospital came under rural area, and people here were not aware of their health and hygiene, so they neglect early diseased condition of their ear which lead it to chronic condition. Also this area is near to river Ganga and Avashyaya and Jala Nimajjana is said to be key factor in etiology of Karnasrava by our Acharya. This may be because of lack of awareness and hygiene towards health and patients from upper class probably take treatment from private practitioner so there was no one from upper class patient in registered patients. Patients having Vata-Kapha dominant Prakriti were more affected 53\%, followed by $27 \%$ Pitta-Kapha Prakriti and 20\% Vata-Pitta Prakriti. As the disease mainly is a Vata Pradhan Tridoshaj Vyadhi. Observation signifies that VataKapha Prakriti patients are more susceptible for this disease. Majority of patients i.e., 13 patients (43\%) had chronicity of more than 1 year, this is because of lack of awareness and negligence towards their health and hygiene, disease reached to chronicity of more than 1 year. In maximum patients i.e., 60\% DNS was present. So DNS could be the region of CSOM in patients. As per classics DNS is one of the main cause of Eustachian tube obstruction and prolonged tubal blockage can result into CSOM[12].

\section{Probable Mode of Action of Bala Taila Nasya}

- Bala Taila is mentioned for Nasya which is measure for treating Karnasrava. Before performing Nasya Karma patient's affected ear was mopped with sterile cotton tipped jobson horn probe on regular basis, which was helpful in relieving discharge and maintaining hygiene.

- Drugs of Dashmoola and Kulatha were used for Drava Dravya and Til Taila as base. All drugs are Ushna Veerya thus, eliminate Vata and Kapha dosha.

- Kalka Dravya such as Saindhava, Agaru, Ella, Jatamansi, Vacha acts as Vatanulomaka thus prevented discharge and enhanced clearance of middle ear secretions vis Eustachian tube.

- Balamoola, Yava, Kola and Godugdha used as Drava Dravya are Sheeta Veerya Dravya thus, eliminated Pitta Dosha.

- Til Taila, Saindhava, Sarjarasa, Devdaru, Kushtha, Tagara, Madhuka, Guduchi having Vrana Shodhana, Vrana Ropana properties which promoted healing of tympanic membrane perforation.

- Laghu- Ruksha Guna of Bilva, Agnimantha, Patala, Shyonaka, Brihati, Kanthkari, Mudgparni, Kulatha, Vanshlochan, Sarjrasa, Agaru, Manjishtha, Chandana, Kushtha, Shatpushpa and Punarnava vitiated Kapha Dosha was eliminated and Ruksha Guna is helpful in preventing discharge.

- Kalka Dravya which contains Madhur Gana (Kakolayadi Gana) Aushadh Dravya are mainly Balya and Dhatuvardhak. So, strengthen the affected Dushya involved in the disease.

- Madhuka, Jeevanti, Ashwagandha, Shatavari, Sariva, Kushtha, Agaru and Godugdha having Rasayana Guna that's how formulation will help in chronic 
conditions, and also Rasayana is mentioned in Samanya Chikitsa for Karna Srava.

- Drug administered as Nasya also showed systemic effects and was useful in relieving Karna Srava.

\section{Probable Mode of Action of Rasnadi Guggulu}

- Some contents of Rasnadi Guggulu such as Rasna, Guduchi, Devdaru, Guggulu, Eranda and Shunthi are Ushna Veerya. Thus, relieving vitiated Vata and Kapha Dosha.

- Eranda and Gaughrita are Madhura in Rasa and Rasna, Devdaru, Guduchi and Guggulu are Tikta in Rasa, which are helpful in relieving Pittashamana Karma.

- Gaughrita have Rasayana Guna, thus, helpful to manage chronic disease.

- Rasnadi Guggulu have anti-inflammatory, analgesic, antipyretic, antiulcer, antisecretory, antibacterial and wound healing properties. Thus, relieve Karnasrava (CSOM).

\section{CONCLUSION}

- Karnasrava can be correlated with CSOM on the basis of etiology, symptoms, prognosis and treatment modalities.

- In Ayurvedic classics, very detailed and practical description of Srava has been described as in modern classics.

- Vata Kapha Prakrti people were more prone for this disease.

- Study shows that people belonging to unhygienic and poor socio-economic status were more prone for the disease.

- Prevalence of Karnasrava (CSOM) was found to be more in 21-30 years age group.

- Study shows that lower middle class people were mostly affected with this disease.

- It is seen that there was very good result of combined therapy in Karnasrava.

- In present study (13.33\%) patients were cured. marked improvement was seen in $46.67 \%$ patients, moderate improvement was seen in $33.33 \%$ patients, mild improvement was seen in $6.67 \%$ patients.

- There were no adverse reactions seen in registered patients during trial.

\section{REFERENCES}

1. Sushruta Samhita with commentary of Dalhana, edited by vaidya Jadavji Trikamji Acharya, edition (2005) Uttartantra, chapter 20, Shloka no. 10.

2. Sushruta Samhita with commentary of Dalhana, edited by vaidya Jadavji Trikamji Acharya, edition (2005) Uttartantra, chapter 20, Shloka no. 15.

3. Agnivesha. Charaka Samhita, Vidyotini Hindi Commentary commentary by Pt Kashinatha Sastri Dr Grakha Natha Chaturvedi, Chaukhambha Bharati Academy, Varanasi (2013). Chikitsa Sthana, chapter 26, Sholka no. 127,128, p. 742 .

4. Ashtanga Hridayam of Vagbhata edited by Vidyotini Hindi Commentary commentary by Kaviraj Atridev Gupta; edited by Vaidya Yadunandana Upadhyaya, Chaukhambha Prakashan Varanasi (2016). Uttarsthana, chapter 17, shloka no. 1-8, p. 691, 692.

5. Ashtanga Samgraha of Vagbhata, Vol. 3 Uttarsthan; Translated by Prof.K.R. Srikantha Murthy, Chaukhambha Prakashan Varanasi (2000). Chapter21, Shloka 4-8, p. 182.

6. Mohan Bansal Disease of Ear, Nose \& Throat. First edition: 2013, Jaypee brothers Medical Publishers (P) LTD; Chapter 19, p.208.

7. WHO/CIBA Foundation Workshop. Prevention of Hearing Impairment from Chronic Otitis Media. WHO/PDH/98.4. London: CIBA Foundation; 1996.

8. Sushruta Samhita with commentary of Dalhana, edited by Vaidya Jadavji Trikamji Acharya, edition (2005) Uttartantra, chapter 21, Shloka no. 40 p. 131.

9. Kaviraj Ambika Dutt Shastri. Moodhgarbhachikitsa chapter 15/30-39 Chikitsasthana, Ayurveda Tatvasandeepika Hindi commentary on Sushruta Samhita Part 1. 2014 reprint Ed.Varanasi; Chaukhamba Sanskrit Samsthan, Shloka no.30-39 pp 14.

10. Sushruta Samhita with commentary of Dalhana, edited by vaidya Jadavji Trikamji Acharya, edition (2005) Uttartantra, chapter 21, Shloka no. 13 p. 128.

11. Yogaratnakar- Vidyotini Hindi Commentary by L. Shastri, Ed, Bramhashankar Shastri, Chaukhamba Sanskrit Series, Varanasi- 1973.

12. Mohan Bansal Disease of Ear, Nose \& Throat. First edition: 2013, Jaypee brothers Medical Publishers (P) LTD; Chapter 17, p.198.

\section{Cite this article as:}

Deepti Negi, Radhakrishna Bishwal, Aditi. Role of Bala Taila Nasya and Rasnadi Guggulu in Karnasrava (Chronic Suppurative Otitis Media). International Journal of Ayurveda and Pharma Research. 2022;10(1):8-13.

https://doi.org/10.47070/ijapr.v10i1.2241

Source of support: Nil, Conflict of interest: None Declared

Disclaimer: IJAPR is solely owned by Mahadev Publications - dedicated to publish quality research, while every effort has been taken to verify the accuracy of the content published in our Journal. IJAPR cannot accept any responsibility or liability for the articles content which are published. The views expressed in articles by our contributing authors are not necessarily those of IJAPR editor or editorial board members. 